\title{
Survei Kondisi Fisik dan Teknik Dasar Bola Voli Putra Pada Masa New Normal Di Klub Sparta Rejang Lebong
}

\author{
Survey Of The Physical Condition and Basic Techniques Of Men's Volleyball \\ During The New Normal Period at The Sparta Rejang Lebong Club

\section{Nurul Syamsi', Yarmani², Arwin ${ }^{3}$} \\ ${ }^{123}$ Pendidikan Jasmani, Universitas Bengkulu,Jl WR Supratman, Bengkulu, 38113, Indonesia
}

\begin{abstract}
Abstrak
Tujuan penelitian ini adalah untuk mengetahui kondisi fisik dan teknik dasar atlet bola voli pada masa New normal di klub Sparta Rejang Lebong. Metode yang digunakan adalah kuantitatif dengan pendekatan survei. Populasi dalam penelitian ini adalah 28 atlet. Teknik sampling yang di gunakan adalah total sampling sehingga sampel yang diambil adalah seluruh pemain Sparta yang berjumlah 28 atlet. Instrumen dan teknik pengambilan data penelitian ini menggunakan Tes Kesegaran Jasmani Indonesia untuk menentukan kondisi fisik dan Battery Voley Ball Tes untuk kemampuan teknik dasar. Analisis data menggunakan rumus kuantitatif persentase. Hasil penelitian ini menyatakan bahwa kondisi fisik atlet berada dalam kategori sedang dengan rata- rata $67,85 \%$ dan untuk tingkat kemampuan teknik dasar berada dalam kategori sedang dengan rata- rata 60,71\% Sehingga kesimpulan yang di dapat dalam penelitian ini adalah kondisi fisik pemain voli klub Sparta Rejang Lebong memiliki kategori sedang dan tingkat kemampuan teknik dasar bola voli juga dalam kategori sedang.
\end{abstract}

Kata kunci: New normal, kondisi fisik, teknik dasar.

\begin{abstract}
The purpose of this study was to determine the physical conditions and basic techniques of volleyball during the New Normal period Rejang Lebong. The method used is a survey with test techniques. The population in this study were 28 athletes. The sampling technique used was total sampling so that the samples taken were all 28 Spartan players. The instruments and data collection techniques for this research used the Indonesian Physical Fitness Test and the Battery Voley Ball Test. The results of this study indicate that the physical condition of the men's volleyball club Sparta volleyball players, the average for athletes was $67.85 \%$ in the moderate category and the level of basic skills technique was in the medium category with an average of $60.71 \%$ The conclusion of this research is the physical condition of the volleyball player of the Sparta, Rejang Lebong, has a moderate category. The level of basic volleyball technical skills is also in the moderate category
\end{abstract}

Key words: New normal, physical condition, basic technique. 


\section{PENDAHULUAN}

New normal adalah istilah yang digunakan di masa pandemi Covid 19, yang artinya kehidupan/ aktifitas masyarakat di mulai kembali secara normal setelah dibukanya kembali himbauan Social distancing (membatasi hubungan sosial secara langsung di masyarakat). Aktivitas pada new normal harus dilaksanakan dengan tetap mematuhi protokol kesehatan, menjaga pola hidup sehat dengan selalu menggunakan masker saat bepergian, mencuci tangan dan menggunakan handsanitizer setelah melakukan aktifitas.

Aktivitas fisik merupakan gerakan tubuh yang dihasilkan oleh otot-otot rangka dan membutuhkan energi (WHO, 2010). Lebih lanjut dijelaskan bahwa aktivitas fisik seperti berlari, berjalan, bermain, angkat beban serta berbagai latihan fisik lainnya merupakan salah satu upaya preventif berbagai jenis penyakit. Gaya hidup, khususnya aktivitas fisik merupakan upaya untuk meningkatkan derajat kesehatan dan meningkatkan usia harapan hidup (Langhammer dalam Nopiyanto, 2020).

Penyebaran corona virus disease 2019 (Covid-19) yang telah menyerang hampir 200 negara di dunia, memberikan dampak tersendiri di sektor pendidikan dan olahraga. Untuk mengatasi hal tersebut, pemerintah mengambil sikap dan membuat kebijakan melarang berkerumun, pembatasan sosial (sosial distancing) dan menjaga jarak fisik (physical distancing), menggunakan masker dan rutin mencuci tangan. Termasuk dalam berolahraga atlet diwajibkan memperhatikan protokol kesehatan. Upaya yang signifkan dilakukan oleh pemerintah dan lembaga pendidikan di semua tingkatan untuk menemukan solusi praktis dalam pembelajaran dirumah ditengah wabah Covid-19 (Raibowo \& Nopiyanto, 2020).

Bola voli merupakan olahraga yang sangat digemari oleh masyarakat Indonesia, bahwa saat ini menduduki peringkat kedua setelah sepak bola, maka tidak heran lagi jika permainan yang sebagian besar ini menggunakan tangan ini dimainkan oleh hampir semua kalangan masyarakat pedesaan, masyarakat, perkotaan, bahkan sekolah-sekolah dasar sampai perguruan tinggi (Indahwati dkk, 2011). 
Bola voli bukan hanya olahraga untuk mengisi waktu luang bagi masyarakat, tetapi juga dijadikan tolak ukur prestasi olahraga di suatu daerah tingkat Desa, Kecamatan, Kabupaten, Provinsi, dan bahkan Nasional. Untuk dapat berpertasi di cabang olahraga bola voli di butuhkan kondisi fisik yang prima dan juga ketrampilan teknik dasar bola voli yang baik.

Salah satu komponen penting untuk meraih satu prestasi dalam olahragaseberapa besar tingkat kondisi fisik yang diperlukan serta bagaimana meningkatkanya melalui latihan, perlu pemahaman yang komprehen sifat terhadap kondisi fisik. Kondisi fisik berhubungan erat dengan kesanggupan tubuh dalam menyelesaikan tugas kerja yang di lakukan. Kondisi fisik sangat menentukan bagi seseorang untuk mengoptimalkan teknik-teknik yang dipelajari, kondisi fisik yang baik merupakan syarat utama untuk menguasai dan mengembangkan suatu ketermpilan teknik olahraga (Syafrudin, 2011). Contohnya seorang spiker dalam permainan bola voli tidak akan dapat memukul bola dengan baik dan keras di atas net bila pemain tersebut tidak memiliki kekuatan lompat yang tinggi, kecepatan gerakan dan fleksibilitas tubuh yang baik.

Teknik dasar adalah cara melakukan atau melaksanakan sesuatu yang dilakukan dengan tujuan tertentu secara efisien dan efektif. Teknik dalam permainan bola voli dapat diartikan sebagai cara memainkan bola dengan efisien dan efektif sesuai peraturan-peraturan permainan yang telah di tetapkan untuk mencapai suatu hasil yang optimal (Purwanto, 2012). Teknik dasar bola voli yang dikembangkan meliputi: (1) servis, (2) passing, (3) umpan, (4) smash, (5) blocking ( Listio, 2011).

Teknik dasar bola voli harus dikuasai lebih dahulu guna pengembangan mutu prestasi permainan bola voli. Salah satu cara yang dilakukan dalam usaha meningkatkan prestasi bola voli dengan cara melakukan pembinaan. Pembinaan olahraga prestasi bola voli membutuhkan waktu yang panjang, terprogram, dan dimulai dari usia dini ( Suharno, 2014).

Klub Sparta Rejang Lebong merupakan klub yang baru berdiri dan masih belum banyak mendapat prestasi di tingkat Kota ataupun Provinsi. Prestasi terbaik yang pernah di raih oleh klub Sparta adalah Juara 2 turnamen (Bupati Cup Rejang 
Lebong) dan juga pernah mendapat juara (1) selama 2 kali dalam turnamen tingkat Kecamatan serta juara 3 satu kali. Pelatih maupun atlet masih sangat kurang memperhatikan tentang kondisi fisik, mereka menyampingkan kepentingan kondisi fisik padahal kondisi fisik membantu saat pertandingan apalagi sampai mengalami long set saat bertanding. Demikian juga halnya dengan teknik dasar passing dan service yang masih kurang baik. Dari latar belakang yang di sebutkan di atas permasalahan yang di bahas dalam penelitian ini adalah mengenai bagaimana kondisi fisik dan kemampuan teknik dasar bola voli di klub Sparta pada masa new normal yang sedang di alami saat ini.

\section{METODE}

Metode yang di gunakan dalam penelitian ini adalah kuantitatif dengan pendekatan survei. Jumlah populasi dalam penelitian ini adalah 28 pemain. Teknik sampling yang digunakan adalah total sampling sehingga semua populasi diikutsertakan menjadi sampel. Variabel dalam penelitian ini adalah 2 variabel yaitu kondisi fisik dan teknik dasar bola voli. Penelitian dilakukan di lapangan bola voli klub Sparta. Instrumen yang di gunakan dalam penelitian ini untuk tes kondisi fisik yang terdiri dari 5 item tes yaitu : 1) Lari 60 meter, 2) Pull Up 60 detik, 3) Sith Up 60 detik, 4) Vertical Jump, 5) Lari 1200 meter. Sedangkan Instrument untuk tes teknik dasar bola voli yaitu Battery Test Volley Ball (Fauzi, 2011) yang terdiri dari 3 item tes yaitu : 1) Servis atas, 2) Passing atas, 3) Passing bawah.

Data yang terkumpul dianalisis dengan rumus kuantitatif presentase (Lestari, 2013)

$$
\mathrm{P}=\frac{\mathrm{f}}{\mathrm{N}} \times 100 \%
$$

Keterangan:

P : Presentase

f : Frekuensi

N : Jumlah Sampel 
Tabel 1. Norma Pengkategorian

\begin{tabular}{ll}
\hline Persentase & Kategori \\
\hline $81 \%-100 \%$ & Sangat Baik \\
$61 \%-80 \%$ & Baik \\
$41 \%-60 \%$ & Sedang \\
$21 \%-40 \%$ & Kurang \\
$0 \%-20 \%$ & Kurang Sekali \\
\hline
\end{tabular}

\section{HASIL}

Penelitian ini menggunakan tes dan pengukuran terhadap 5 tes fisik dan 3 tes teknik dasar yang digunakan untuk menunjang kemampuan fisik dan teknik bagi pemain bola voli. Teknik analisis data yang digunakan untuk menguji data dalam penelitian ini adalah analisis deskriptif persentase. Dimana hasil dari data penelitian dihitung dalam jumlah persen berapa pemain yang dalam katagori baik sekali, baik, sedang, kurang dan kurang sekali.

\section{Tes kondisi Fisik Keseluruhan}

Tingkat kondisi fisik pemain voli klub Sparta secara keseluruhan yang berjumlah 28 atlet yaitu: 6 atlet masuk kategori baik (21,43\%), 19 atlet masuk kategori sedang $(67,85 \%)$ dan $3(10,72 \%)$ atlet dalam kategori kurang.

Tabel 2. Hasil Tes Kondisi Fisik

\begin{tabular}{llll}
\hline No & Kategori & Frekuensi & Persentase \\
\hline 1 & Baik Sekali & 0 & $0 \%$ \\
2 & Baik & 6 & $21,43 \%$ \\
3 & Sedang & 19 & $67,85 \%$ \\
4 & Kurang & 3 & $10,72 \%$ \\
5 & Kurang Sekali & 0 & $0 \%$ \\
\hline & Jumlah & 0 & $100 \%$ \\
\hline
\end{tabular}

\section{Tes Ketrampilan Teknik Dasar Keseluruhan}

Tes ketrampilan teknik dasar pada Klub bola voli Sparta putra adalah sebagai berikut, untuk pemain putri terdapat 16 pemain yang memperoleh nilai baik (89,28\%), 12 pemain memperoleh nilai sedang $(10,72 \%)$. 
Tabel 3. Hasil Tes Teknik Dasar

\begin{tabular}{llll}
\hline No & Kategori & Frekuensi & Persentase \\
\hline 1 & Baik Sekali & 0 & $0 \%$ \\
2 & Baik & 5 & $17,85 \%$ \\
3 & Sedang & 20 & $71,43 \% \%$ \\
4 & Kurang & 3 & $10,72 \%$ \\
5 & Kurang Sekali & 0 & $0 \%$ \\
\hline & Jumlah & 28 & $100 \%$ \\
\hline
\end{tabular}

\section{PEMBAHASAN}

\section{Kondisi Fisik}

Hasil penelitiaan tes kondisi fisik klub Sparta Desa IV Suku Menanti Kecamatan Sindang Dataran Kabupaten Rejang Lebong, dalam kategori baik sebanyak 6 atlet (21,43\%), dalam kategori sedang sebanyak 19 atlet $(67,85 \%)$ dan dalam kategori kurang sebanyak 3 atlet $(10,72 \%)$. Jadi dapat di simpulkan dari hasil tes kondisi fisik yang telah di lakukan, atlet klub Sparta Desa IV Suku Menanti Kecamatan Sindang Dataran Kabupaten Rejang Lebong sebagian besar memiliki kondisi fisik dalam kategori (sedang). Salah satu faktor yang mempengaruhi keberhasilan seorang pemain mengenai kondisi fisiknya adalah faktor latihan. Latihan adalah sesuatu proses yang sistematis, yang dilakukan berulang- ulang, kian hari jumlah beban latihannya semakin bertambah. Kemampuan seseorang untuk melakukan sesuatu sering kali harus didukung oleh latihan yang keras.

Pada masa New normal ini, Klub Sparta masih melakukan latihan walaupun tidak seintensif latihan seperti biasanya. Latihan di lakukan hanya 2 kali dalam seminggu dan latihan yang di lakukan hanya latihan teknik dasar dengan game play (bermain langsung bola voli). Sedangkan untuk latihan fisik dilakukan pribadi oleh atlet di rumah masing-masing, hal ini merupakan kebijakan dari pelatih terkait dengan peraturan pemerintah karna tidak boleh adanya aktifitas di luar rumah yang mengumpulkan banyak masa (Nopiyanto, 2020). Dari hasil tes kondisi fisik yang telah di lakukan sebagian besar atlet yang kondisi fisiknya berada dalam kategori sedang dan kurang di karenakan latihan kondisi fisik yang 
kurang teratur, bahkan tidak melakukan latihan sama sekali. Berikut penjelasan hasil penelitian untuk tiap item tes yang digunakan yaitu:

\section{a) Kecepatan}

Dari hasil tes lari kecepatan dapat diketahui bahwa terdapat $1(3,57 \%)$ atlet dengan nilai baik, $17(60,71 \%)$ atlet dengan nilai sedang dan $10(35,72 \%)$ atlet dengan nilai kurang. Latihan kecepatan akan sangat membantu pemain untuk mendapatkan kekuatan otot tungkai yang baik. Pemakaian daya otot ini dilakukan dengan tenaga makimal dalam waktu singkat dan pendek. Daya otot dipengaruhi oleh kekuatan otot dan kecepatan kontraksi otot sehingga semua faktor yang mempengaruhi kedua hal tersebut akan mempengaruhi daya otot. Hasil tes kecepatan ini di simpulkan bahwa atlet Sparta rata-rata memiliki kekuatan otot tungkai yang sedang. Hasil ini di pengaruhi oleh beberapa faktor kurang intensif latihan, serta tidak adanya latihan yang berkelanjutan yang bertahap. Kecepatan dalam permainan bola voli sangat di perlukan untuk melatih reflek, agility (kelincahan) dalam pasing game. Biasanya pemain bola voli masih belum memiliki reflek yang baik. Hal tersebut dapat dilihat ketika dalam pertandingan masih sering poin masuk melalui bola tipuan, dimana respond an pergerakan pemain masih sering terlamabat.

\section{b) Kekuatan Otot Bahu}

Dari hasil tes pull up dapat diketahui bahwa terdapat 7 (25\%) atlet dengan nilai baik, 17 (60,71\%) atlet dengan nilai sedang dan 4 (14,29\%) atlet dengan nilai kurang. Latihan angkat tubuh akan sangat membantu pemain untuk mendapatkan kekuatan otot bahu yang baik. Pemakaian daya otot ini dilakukan dengan tenaga makimal dalam waktu singkat dan pendek. Daya otot dipengaruhi oleh kekuatan otot dan kecepatan kontraksi otot sehingga semua faktor yang mempengaruhi kedua hal tersebut akan mempengaruhi daya otot. Setelah melakukan tes angkat tubuh selama 60 detik menghasilkan hasil untuk atlet diketahui bahwa atlet Sprata memiliki kekuatan otot bahu dalam kategori sedang.

Hal ini di pengaruhi oleh beberapa faktor salah satunya yaitu salahnya teknik pengambilan nafas saat melakukan tes. Dalam kegiatan olahraga kekuatan otot bahu sangat diperlukan untuk mencapai hasil yang maksimal, dimana dengan kekuatan yang dikeluarkan pemain diharapkan mampu memberikan pengaruh 
yang baik dalam mencapai prestasi olahraga yang digelutinya (Ismaryati, 2011). Kekuatan otot bahu di perlukan dalam permainan bola voli, diantaranya yaitu untuk kuda - kuda penerimaan pasing, serta untuk akurasi pukulan servis ataupun smash. Kekuatan otot bahu yang baik akan sangat mempengaruhi hal tersebut, apabila kekuatan otot bahunya baik maka akan semakin keras dan baik pula pukulan servis dan juga smashnya.

\section{c) Kekuatan Otot Perut}

Dari hasil tes kekuatan otot perut dapat diketahui bahwa terdapat 12 (42,85\%) atlet dengan nilai baik sekali, 9 (32,15\%) atlet dengan nilai baik, 7 $(25 \%)$ atlet dengan nilai sedang. Pada saat seorang pemain melompat untuk memukul bola maka semua organ tubuhnya akan bekerja atau berkontraksi terutama dibagian perut. Oleh sebab itu diperlukan daya otot perut agar pemain memiliki daya tahan yang baik pada saat bermain bola voli. Dengan berlatih sit-up maka akan membantu membentuk otot perut dengan baik. Latihan ini jika dilakukan secara rutin juga akan sangat membuat bentuk perut semakin menarik (tidak terjadi penimbunan lemak) daya tahan otot perut sangat dipengaruhi oleh kekuatan otot perut dan kecepatan kontraksi otot perut itu sendiri sehingga semua faktor yang mempengaruhi kedua hal tersebut akan mempengaruhi daya tahan otot perut.

Setelah melakukan tes kekuatan otot perut diketahui bahwa atlet Sparta memiliki kekuatan otot perut dalam kategori baik sekali. Kelentukan (flexibility) dari otot perut adalah segala efektivitas seseorang dalam menyesuaikan diri untuk segala aktivitas dengan penguluran tubuh ditandai dengan fleksibilitas persendian pada seluruh tubuh (Sajoto dalam Mustofa, 2016). Dalam permainan bola voli kekuatan otot perut berpengaruh terhadap lentingan posisi badan saat melakukan smash

\section{d) Power Otot Tungkai}

Dari hasil tes power otot tungkai dapat diketahui bahwa terdapat $6(21,42 \%)$ atlet dengan nilai baik dan 22 (78,58\%) atlet dengan nilai sedang. Tidak terdapat pemain dalam kategori baik sekali, kurang dan kurang sekali. Pada saat pemain bola voli melakukan smash, mereka akan berusaha sekuat mungkin agar loncatan 
yang dihasilkan dapat tinggi dan mengenai sasaran. Menurut (Harsono dalam Sihombing, 2019) menyatakan bahwa power otot tungkai adalah kemampuan otot untuk mengerahkan kekuatan maksimal dalam waktu yang sangat cepat. Dengan berlatih loncat tegak (vertikal jump) diharapkan seorang pemain memiliki loncatan yang tinggi sehingga dapat memenangkan perebutan bola atas. Setelah melakukan tes vertikal jump untuk atlet menunjukan bahwa atlet Sparta memiliki daya ledak otot tungkai dalam kategori sedang. Hasil penelitian ini di pengaruhi oleh beberapa faktor di antaranya yaitu kesalahan dalam melakukan lompatan dan pengambilan posisi awalan tolakan. Power otot merupakan gabungan dari kekuatan dan kecepatan dimana kemampuan yang dilakukan dapat semaksimal mungkin.

\section{e) Daya Tahan}

Dari hasil tes daya tahan dapat diketahui bahwa terdapat $11(39,28 \%)$ atlet dengan nilai baik, $3(10,72 \%)$ atlet dengan nilai sedang, 12 (42,85\%) atlet dalam kategori kurang dan $2(7,15 \%)$ atlet dengan nilai kurang sekali. Dari hasil tes yang dilakukan daya tahan yang di miliki atlet Sparta berada dalam kategori kurang. Salah satu bentuk latihan daya tahan yaitu lari jarak jauh (1200 Meter) ini bertujuan agar pemain memiliki daya tahan cardiorespiratori yang sangat bagus.

Dengan daya tahan tubuh yang bagus pemain tetap menjaga permainannya selama pertandingan berlangsung. Daya tahan (endurance) adalah kemampuan tubuh seseorang untuk melawan kelelahan yang timbul saat melakukan aktivitas dalam waktu yang cukup lama (Pramono, 2012). Permainan bola voli merupakan salah satu permainan yang dilakukan cukup lama, sehingga diperlukan daya tahan tubuh yang bagus.

\section{Keterampilan Teknik Dasar}

\section{a) Tes Service atas}

Terlihat pada tabel bahwa kemampuan atlet dalam melakukan servis adalah untuk kategori baik sekali sebanyak 0\%, kategori baik sebanyak 5 pemain (17,85\%), kategori sedang sebanyak 20 pemain $(71,43 \%)$, kategori kurang sebanyak 3 pemain $(10,72 \%)$ dan kategori kurang sekali sebanyak 0\%. Hal ini dapat dipengaruhi oleh beberapa faktor kurang intensif latihan melakukan servis, 
sehingga menyebabkan perkenaan bola tidak tepat yang menyebabkan bola tidak sempurna dipukul dan jauh dari sasaran.

\section{b) Tes Passing Atas}

Dari hasil tes kemampuan melakukan passing atas untuk atlet yang terlihat pada tabel bahwa kemampuan atlet dalam melakukan passing atas adalah dengan kategori baik sekali 0 atlet persentase (0\%), kategori baik sebanyak 7 atlet $(25 \%)$, kategori sedang sebanyak 12 atlet dengan persentase 42,860\%, kategori kurang sebanyak 9 atlet $(32,14 \%)$ dan kategori kurang sekali sebanyak(0\%). Hal ini menunjukkan bahwa dapat dipastikan pemain bola voli di Klub Sparta Rejang Lebong mempunyai kemampuan pasing atas dalam kategori sedang. Hasil ini dapat dipengaruhi oleh beberapa faktor antara lain adalah bola menyentuh telapak tangan dan tertahan, bola bergerak keatas bukan meninggi kedepan, posisi kaki tidak seimbang sehingga arah bola tidak sempurna. Selain itu postur tubuh juga berpengaruh, postur tubuh yang rendah akan lebih sulit dalam mengarahkan bola ke sasaran, tetapi untuk siswa yang memiliki postur tubuh tinggi akan lebih mudah dalam mengarahkan bola ke sasaran.

\section{c) Tes Passing Bawah}

Dari hasil tes kemampuan melakukan passing bawah untuk kategori baik sekali sebanyak 14 atlet (50\%), kategori baik sebanyak 14 (50\%), kategori sedang sebanyak $0 \%$, kategori kurang sebanyak $0 \%$ dan kategori kurang sekali sebanyak $0 \%$. Dilihat dari hasil yang ada, hal ini dapat dipengaruhi oleh beberapa faktor antara lain posisi kaki yang seimbang sehingga arah bola menjadi sempurna, perkenaan bola yang tepat pada lengan, sehingga pantulan bola menjadi sempurna yang menyebabkan pantulan bola mudah untuk dijangkau.

\section{KESIMPULAN}

Kondisi fisik pemain voli Klub bola voli putra Sparta, rata-rata untuk atlet kategori sedang. Persentase terbesar dari masing- masing aspek kondisi fisik adalah kecepatan dalam kategori sedang. Kekuatan otot bahu dalam kategori sedang. Kekuatan otot perut kategori baik sekali. Power otot tungkai dalam kategori sedang dan daya tahan dalam kategori kurang. Tingkat kemampuan teknik dasar bola voli pada Klub bola voli putra Sparta berada dalam kategori 
sedang. Persentase terbesar dari masing- masing aspek adalah untuk tes service atas kategori sedang. Passing atas kategori sedang. Untuk Passing bawah kategori baik.

\section{REFERENSI.}

Fauzi, M . S., (2013). Rules of the Game | volleyball. Tersedia dalam : http://www.Fivb.org/EN/Refereeing-Rules/RulesOfTheGame_VB.asp. [diakses pada tanggal 9 Maret 2014].

Indahwati, Sunardi, D \& W.(2013). Bola Voli. Surakarta : UNS Press.

Ismaryanti. (2011). Tes dan Pengukuran Olahraga. Jateng: Sebelas Maret University Press.

Listio (2011) Analisis Hubungan Kondisi Fisik dan Keterampilan Teknik Dasar Voli Pada Team Bola Voli Di SMK MUHAMMADIYAH Belik Pemalang. Semarang : UNESA

Mustofa, H. (2016). Perbedaan Pengaruh Metode Latihan Berbeban Dan Plaiometrik Terhadap Peningkatan Keterampilan Teknik Dasar Bola Basket Ditinjau Dari Koordinasi Mata-Tangan (Studi Eksperimen Latihan Berbeban Dan Plaiometrik Pada Atlet Remaja Putra Klub Bola Basket YUSO Yogyakarta) (Doctoral dissertation, UNS (Sebelas Maret University).

Nopiyanto, Y. E. (2020). Hambatan Guru Pendidikan Jasmani Generasi 80-an dalam Pembelajaran Daring di Tengah Pandemi Covid-19. Jurnal Sporta Saintika, 5(2), 139-148.

Nopiyanto, Y. E., Raibowo, S., Sugihartono, T., \& Yarmani, Y. (2020). Pola Hidup Sehat Dengan Olahraga dan Asupan Gizi Untuk Meningkatkan Imun Tubuh Menghadapi Covid-19. Dharma Raflesia: Jurnal Ilmiah Pengembangan dan Penerapan IPTEKS, 18(2), 90-100.

Purwanto, D. (2012). Survey Kondisi Fisik Dan Keterampilan Teknik Dasar Bola Voli Pada Klub Bola Voli Putri Bravo Banjarnegara Tahun 2012 (Doctoral dissertation, Universitas Negeri Semarang).

Raibowo, S., \& Nopiyanto, Y. E. (2020). Proses Belajar Mengajar PJOK Di Masa Pandemi Covid-19. Stand: Journal Sports Teaching and Development, 1(2), 112-119.

Risma Putri, S. A., \& Fajar, M. (2020). Personality Of Volleyball Athletes Faculty Student Activity Unit (UKMF) PGRI University Of Palembang. Kinestetik: Jurnal Ilmiah Pendidikan Jasmani, 4(2), 128-133. 
Sihombing, S. (2019). Hubungan Panjang Tungkai dan Daya Ledak Otot Tungkai Dengan Hasil Lari Sprint 100 Meter. Kinestetik: Jurnal Ilmiah Pendidikan Jasmani, 3(2), 256-261.

Sudiarto, F. K. (2013). Hubungan Daya Ledak Tungkai, Kekuatan Lengan Dan Kelentukan Pergelangan Tangan Dengan Hasil Back Attack Bola Voli Putra Bahurekso Tahun 2013 (Doctoral dissertation, Universitas Negeri Semarang).

Suharno, H. P. (2014). Teknik Dasar Permainan Bola Voli. Bandung: Alfabeta Syafruddin. (2011). Ilmu Kepelatihan Olahraga. Padang : UNP. 